\title{
ANALYSIS OF MAIZE FARMERS' ACCESS TO AGRICULTURAL INFORMATION IN AIYEDIRE LOCAL GOVERNMENT AREA, OSUN STATE, NIGERIA
}

\author{
Adebayo, S.A. ${ }^{*}$ Olorunfemi, D. O. and Odedoyin, C. B. \\ Department of Agricultural Extension and Rural Development, \\ University of Ilorin, Ilorin, Nigeria \\ *Corresponding author: sijuadeadebayo@yahoo.com
}

\begin{abstract}
This study analyses maize farmers' access to agricultural information in Aiyedire Local Government Area of Osun state, Nigeria. The specific objectives of this study were to describe the socio-economic characteristics of the maize farmers, identify access of maize farmers to agricultural information, determine the level of access to agricultural information and identify the sources of agricultural information to the maize farmers. A structured questionnaire was used to randomly sample 105 respondents used for this study. Descriptive statistics such as frequency distribution and percentage was used to analyse the socio-economic characteristics, sources of information and access to agricultural information while a three-point Likert-type scale was used to analyse the level of access of the maize farmers to agricultural information The result showed that the majority (87.6\%) of the farmers were male, married (84.4\%) and $42.9 \%$ of them had secondary education. The majority of the farmers (89.5\%) had farm size of about five hectares while those with farming experience less than 10 years was $39 \%$. Fiftyeight percent of the farmers had household size of 4-6 persors and $69.5 \%$ of them had contacts with extension agents while $49.5 \%$ of the farmers were members of agricultural organizations. The results further showed that the farmers had access to information on improved maize varieties, with a mean score of 2.90 while they had limited access to information on mechanized method of harvesting maize, with mean score of 1.07. Therefore, the study recommends that extension agencies should provide up-to-date information on new and improved technological implement like sheller, tractors, among others, for maize farmers.
\end{abstract}

Keywords: Agricultural Information, Access, Maize Farmers, Nigeria 


\section{INTRODUCTION}

Maize is one of the most important grains in Nigeria, not only on the basis of the number of farmers that engage in its cultivation, but also in its economic value. It is a cereal plant that produces grains that can be cooked, roasted, fried, ground, pounded or crushed to prepare various food items like pap, 'tuwo' 'gwate', 'dokunnu' and host of others. All these food types are readily available in various parts of Nigeria among different ethnic groups. According to Khawar et al, (2007), maize has a variety of uses. The grain, leaves, stalk, tassel and cob can all be used to produce a large variety of food and non-food products (IITA, 2001). Moreover, studies in maize production in different parts of Nigeria have shown an increasing importance of the crop amidst growing utilization by food processing industries and livestock feed mills (Ogunsumi et al., 2005; Khawar et al, 2007; Abaduhaman and Kolawole, 2008). According to Aina et al. (1995), information has a vital role to play in improving and sustaining agricultural production of any nation. Furthermore, Fawole (2008) reported that information dissemination to farmers in the rural areas is an integral part of the clamor for adoption of innovations and agricultural development. Over the years, maize farmers depend on indigenous farming system instead of practicing the new improved system. Although, today there have been numerous varieties of new and improved information on maize farming system, however, such information will not be utilized if it is not accessible. Information may be physically accessible but may not be intellectually accessible (Opara, 2010). This is because a host of social, economic and psychological factors influence the rate of agricultural information use (Akande, 1999). Moreover, Adedoyin (2006) identified lack of information about the borrowers, lack of proper collateral among the poor women farmers as some of the reasons that make it difficult for rural poor to have access to financial institutions. Therefore, agricultural information should be simplified to the farmers in such a way that it can be easily understood and utilized. Therefore, the objectives of the study were to

a. describe the socio-economic characteristics of the maize farmers;

b. identify access of maize farmers to agricultural information;

c. determine the level of access to agricultural information; and

d. identify the sources of agricultural information available to the maize farmers

\section{Hypothesis of the study}

$\mathrm{HO}_{1}$ : There is no significant relationship between the socio-economic characteristics of the maize farmers and their access to agricultural information. 


\section{METHODOLOGY}

The study was carried out in Aiyedire local government in Osun state. It has its headquarters in lle-ogbo town at $7^{\circ} 47^{\prime} 00^{\prime \prime} \mathrm{N} 4^{\circ} 12^{\prime} 00^{\prime \prime} \mathrm{E}$. It has an area of $262 \mathrm{~km}^{2}$ and a population of 75,846 at the 2006 national census. The postal code of the area is 232 . It is an agrarian community.

The population for this studywas maize farmers in Aiyedire local government in Osun State. Aiyedire Local Government was purposively chosen for the study base on the premise that they are maize growers. Three communities were randomly selected in the local government; these are lle-ogbo, Kuta and Oluponna towns. Thirty-five (35) maize farmers were randomly selected from each of these communities to give a total sample size of one hundred and five (105) respondents.

The data was analyzed using frequency distribution, Likert-type scale and correlation analysis. The farmers' response to level of access to agricultural information was rated on a three-point Likert-type scale. The respondents were asked to rate the statements as follows 1(regularly), 2(often), 3(rarely). The actual mean is 2.00 based on the rating scale; hence, a mean greater than 2.00 denotes a positive response while a mean less than 2.00 denotes negative response.

\section{RESULTS AND DISCUSSION \\ Socio-economic characteristics of the respondents}

Table 1 shows the socio-economic characteristics of the respondents. The Table shows that $23.8 \%$ of the respondents were between $41-50$ years of age. This finding implies that majority of the farmers were within their active years. This is similar to the findings of Adesiji et al., (2012) that reported that the mean age among cashew farmers was 46.5 years. The table shows that the majority of the maize farmers $(97.6 \%)$ were male. This shows that male participate more in farm activities in the area than female and this goes in line with King (1992) who revealed that men perform more difficult farming operations, such as land preparation (clearing bushes and making of mounds and ridges) while women and children perform lighter operations, such as planting, fertilizer application, and weeding. The result in table 1 further shows that the majority of the farmers $(84.8 \%)$ were married and $42.9 \%$ had secondary education. This implies that the farmers are fairly educated and this has a positive implication for sourcing information. The reports of FAO (1993) and Zijp (1994) confirm that agricultural information transfer, sourcing and usage thrive better in places where farmers are highly educated. The table further shows that the majority of the farmers $(89.5 \%)$ had a farm size of not less than five hectares. This implies that most of the maize farmers have small farm holdings in the study area. Many of the farmers have farming experience of about ten years (39\%). This suggests that most of the farmers in the study area have been involved in agriculture for a long 
time and have great farming experience. Many $(58.1 \%)$ of the respondents have household size of $4-6$ people and $68.5 \%$ of them have contact with extension agents. This implies that majority of the maize farmers were reached with adequate information by the extension agents. This is in line with Ogunwale (2005) who asserted that contact with extension agents under Training and Visit ( $T$ and V) system brings about remarkable increase in knowledge of farmers about farm technologies and practices. The result also shows that about $50 \%$ of the farmers belong to one organization or the other. This implies that the farmers may have access to information through the organization which can help in their production. The findings of Adebayo and Adekunle, (2016) shows that farmers belonging to a group enjoy a lot of benefits and are able to accomplish a lot collectively than individually.

Table 1: Distribution of the respondents by their socio-economic status $(n=105)$

\begin{tabular}{lll}
\hline Variables & Frequency & Percentage \\
\hline Age & 21 & 20.0 \\
$\leq 30$ & 17 & 16.2 \\
$31-40$ & 25 & 23.8 \\
$41-50$ & 21 & 20.0 \\
$51-60$ & 21 & 20.0 \\
$\geq 60$ & & \\
Gender & 92 & 87.6 \\
Male & 13 & 12.4 \\
Female & & \\
& & \\
Marital status & 13 & 12.4 \\
Single & 89 & 84.7 \\
Married & 5 & 2.9 \\
Divorced & & \\
& & \\
Educational status & & 21.0 \\
Non formal & 22 & 16.2 \\
Primary & 17 & 42.9 \\
Secondary & 45 & 20.0 \\
Tertiary & 21 & \\
& & 63.8 \\
Religion & 67 & \\
Islam & &
\end{tabular}




\begin{tabular}{|c|c|c|}
\hline Christianity & 38 & 36.2 \\
\hline \multicolumn{3}{|l|}{ Farm size } \\
\hline$\leq 5.0$ & 94 & 89.5 \\
\hline $5.1-10.0$ & 7 & 6.7 \\
\hline $10.1-15.0$ & 2 & 1.9 \\
\hline $15.1-20.0$ & 1 & 1.0 \\
\hline$\geq 20$ & 1 & 1.0 \\
\hline \multicolumn{3}{|c|}{ Farm experience } \\
\hline$\leq 10$ & 41 & 39.0 \\
\hline $11-20$ & 31 & 29.5 \\
\hline $21-30$ & 11 & 10.5 \\
\hline $31-40$ & 12 & 11.4 \\
\hline$\geq 41$ & 10 & 9.5 \\
\hline \multicolumn{3}{|c|}{ Household size } \\
\hline $0-3$ & 25 & 23.8 \\
\hline $4-6$ & 61 & 58.1 \\
\hline $7-9$ & 14 & 13.3 \\
\hline $10+$ & 5 & 4.8 \\
\hline \multicolumn{3}{|c|}{$\begin{array}{l}\text { Contact with extension } \\
\text { agent }\end{array}$} \\
\hline Yes & 73 & 69.5 \\
\hline No & 32 & 30.5 \\
\hline \multicolumn{3}{|c|}{$\begin{array}{l}\text { Organization } \\
\text { membership }\end{array}$} \\
\hline Yes & 52 & 49.5 \\
\hline No & 53 & 50.5 \\
\hline
\end{tabular}

Source: Field Survey, 2015.

\section{Access of maize farmers to agricultural information}

Table 2 reveals that the farmers have access to information on the technique of production which include the use of tractors for land clearing $(80 \%)$, ploughing $(81 \%)$, ridging $(75.2 \%)$, harrowing $(72.4 \%)$, and application fertilizer (93.3\%). This implies that the maize farmers are well informed on the techniques of production. The table also shows that majority of the 
respondents indicated that they had access to agricultural information on the control of pest and diseases such as improved maize varieties (97.1\%), selection and rate of chemical application for weed control (93.3\%), treated maize seed (99\%), improved method of controlling of pests and diseases of maize (80\%), and improved method of preventing pests and diseases on maize $(81 \%)$. This implies that the maize farmers are conversant with the pest and diseases that poses threat and challenge to their production. The result is in line with the works of Konradsen et al (2003) and Coronado et al (2004) that discovered that pesticides have substantially contributed to the controlling of pests and increasing crop yields in meeting the food demand of escalating population and control of vector-borne diseases.

On marketing, it was discovered that $(92.4 \%)$ of the farmers have access to information on market outlet for harvested maize while $73.3 \%$ of the respondents indicated to have access to prevailing maize crop prices in the market. About $46.7 \%$ of the farmers indicated to have access to information on record keeping, $14.3 \%$ indicated to have access to information on marketing of maize through cooperatives, while $38.1 \%$ reported to have access to information on loan acquisition/credit facilities. This implies that the farmers are not well informed on record keeping and other marketing outlets. This may be as a result of the farmers not keeping record of their produce and only depend on open market for the sales of their produce, as a result, may not be eager to find out information on these areas. Moser et al (2005) found that access to market information can enhance farmers' access to markets through better negotiation and meeting market demands. Furthermore, Uchezuba et al. (2009) discovered that marketing information and market prices guide the farmer in making informed decisions, and assist farmers for planning at pre-planting stage and to sell the surpluses that have been produced. In the absence of marketing information, the retail end of the industry does not respond to supply and demand and the pricing is artificially static or unchanged (Xaba \& Masuku, 2012).

On preservation and storage, it was revealed that $60 \%$ of the respondents have access to information on soil management practices, while $38.1 \%$ of the respondents have access to information on mechanized method of shelling maize grain, only $2.9 \%$ have access to information on payment of compensation for crop, also $2.9 \%$ have access to information on mechanized method of harvesting maize and $11.4 \%$ respondents have access to information on storage of maize in modern cribs/silo. This implies that the maize farmers are not well informed on preservation and storage. This can be as a result of the farmers not using mechanized implements and modern storage facilities. On erosion and flooding, the result shows that $86.7 \%$ of the farmers have access to information on improved plant spacing for maize while $78.1 \%$ of the respondents have access to weather forecast information on maize planting. $33.3 \%$ of the farmers have access to information on soil fertility testing, $23.8 \%$ have access to environmental protection on land and $1.9 \%$ of the farmers have access to information on government policies on land acquisition. This result implies that majority of the farmers have 
access to information on erosion and flooding especially in the area of improve plant spacing and weather forecast maybe because this serves as major threat to them. However, the farmers have inadequate access to information on soil fertility testing, environmental protection on land and government policies on land acquisition.

Table 2: Distribution of the respondents by their access to agricultural information on maize

\begin{tabular}{|c|c|c|}
\hline Technique in Production* & frequency & Percentage \\
\hline Use of tractor for land clearing & 84 & 80 \\
\hline Method of fertilizer application e.g. foliar, ring & 98 & 93.3 \\
\hline Use of tractor for ploughing & 85 & 81.0 \\
\hline Use of tractor for ridging & 79 & 75.2 \\
\hline Use of tractor for harrowing & 76 & 72.4 \\
\hline \multicolumn{3}{|l|}{ Pest and Disease } \\
\hline Improve maize varieties & 102 & 97.1 \\
\hline $\begin{array}{l}\text { Selection and rate of chemical application for weed } \\
\text { control }\end{array}$ & 98 & 93.3 \\
\hline Treated maize seed & 104 & 99.0 \\
\hline $\begin{array}{l}\text { Improved method of Controlling of pests and } \\
\text { diseases of maize }\end{array}$ & 84 & 80.0 \\
\hline $\begin{array}{l}\text { Improved method of preventing pests and } \\
\text { diseases of maize }\end{array}$ & 85 & 81.0 \\
\hline \multicolumn{3}{|l|}{ Marketing } \\
\hline Better record keeping on sales produced & 49 & 46.7 \\
\hline Market outlet for harvested maize & 97 & 92.4 \\
\hline Marketing of maize produced through cooperatives & 15 & 14.3 \\
\hline Prevailing maize crop prices in the market & 77 & 73.3 \\
\hline Loan acquisition/credit facilities & 40 & 38.1 \\
\hline \multicolumn{3}{|l|}{ Preservation and Storage } \\
\hline Mechanized method of shelling maize grain & 40 & 38.1 \\
\hline Storage of maize in modern cribs/silo & 12 & 11.4 \\
\hline Payment of compensation for crop & 3 & 2.9 \\
\hline Soil management practices & 63 & 60.0 \\
\hline Mechanized method of harvesting maize & 3 & 2.9 \\
\hline \multicolumn{3}{|l|}{ Erosion/Flooding } \\
\hline Weather forecast information on maize planting & 82 & 78.1 \\
\hline Environmental protection on land & 25 & 23.8 \\
\hline
\end{tabular}




\begin{tabular}{lll}
\hline Improved plant spacing for maize & 91 & 86.7 \\
Government policies on land acquisition & 2 & 1.9 \\
Soil fertility testing & 35 & 33.3 \\
\hline
\end{tabular}

Source: Field Survey, 2015. ${ }^{*}$ Multiple Response

\section{Level of access of maize farmers to agricultural information}

In Table 3, farmer's response to level of access to agricultural information was rated on a 3 point Likert type scale. The results reveal a positive response to access to agricultural information on some technique of production, marketing and control of pest and disease. The most prominent response as ranked by the farmers were statements that they have 'access to information on the use of treatment for land clearing' (2.41), 'method of fertilizer application' (2.59), 'improved maize varieties' (2.90). This may be because the respondents are aware of the optimum yield production and increase in income which makes a positive influence on their way of living. The findings of Blait (1996) showed that rural agricultural development could be enhanced through adequate access to knowledge and information in areas of new agricultural technologies, early warning systems (drought, pests, diseases etc), improved seedlings, fertilizer, credit, market prices among others.

It was discovered that 'Selection and rate of chemical application for weed control' (2.56), 'treated maize seeds' (2.86) also has prominent rank result in level of access to agricultural information. This implies that most of the respondents have high level of access to agricultural information and this maybe because they have been enlightened on the benefit of using it like protection on seedlings and optimum harvest.

Table 3: Distribution of respondents by levels of access to agricultural information on maize

\begin{tabular}{|c|c|c|c|c|c|c|c|}
\hline Agricultural Information & Regularly & Often & Rarely & $\begin{array}{l}\text { Weight } \\
\text { ed } \\
\text { score }\end{array}$ & $\begin{array}{l}\text { Mean } \\
\text { score }\end{array}$ & S.D & Rank \\
\hline Improve maize varieties & $96(91.4)$ & $8(7.6)$ & $1(1.0)$ & 304.5 & 2.90 & 0.326 & $1^{\text {st }}$ \\
\hline Treated maize seed & $92(87.6)$ & $11(10.5)$ & $2(1.9)$ & 300.3 & 2.86 & 0.403 & $2^{\text {nd }}$ \\
\hline $\begin{array}{l}\text { Method of fertilizer application } \\
\text { e.g. foliar, ring }\end{array}$ & $71(67.6)$ & $25(23.8)$ & $9(8.6)$ & 272 & 2.59 & 0.646 & $3^{\text {rd }}$ \\
\hline $\begin{array}{l}\text { Selection and rate of chemical } \\
\text { application for weed control }\end{array}$ & $69(65.7)$ & $26(24.8)$ & $10(9.5)$ & 268.8 & 2.56 & 0.664 & $4^{\text {th }}$ \\
\hline Use of tractor for ploughing & $65(61.9)$ & $21(20.0)$ & 19(18.1) & 256 & 2.44 & 0.784 & $5^{\text {th }}$ \\
\hline
\end{tabular}




\begin{tabular}{|c|c|c|c|c|c|c|c|}
\hline $\begin{array}{l}\text { Market outlet for harvested } \\
\text { maize }\end{array}$ & $65(61.9)$ & $20(19.0)$ & $20(19.0)$ & 255.15 & 2.43 & 0.795 & $6^{\text {th }}$ \\
\hline Use of tractor for land clearing & $64(61.0)$ & $21(20.0)$ & $20(19.1)$ & 254 & 2.41 & 0.817 & $7^{\text {th }}$ \\
\hline $\begin{array}{l}\text { Weather forecast information on } \\
\text { maize planting }\end{array}$ & $63(60.0)$ & $22(21.0)$ & $20(19.0)$ & 253.05 & 2.41 & 0.793 & $8^{\text {th }}$ \\
\hline $\begin{array}{l}\text { Improved method of Controlling } \\
\text { pests and diseases of maize }\end{array}$ & $60(57.1)$ & $26(24.8)$ & 19(18.1) & 250.95 & 2.39 & 0.778 & $9^{\text {th }}$ \\
\hline $\begin{array}{l}\text { Improved plant spacing for } \\
\text { maize }\end{array}$ & $63(60.0)$ & $20(19.0)$ & $22(21.0)$ & 250.95 & 2.39 & 0.814 & $10^{\text {th }}$ \\
\hline $\begin{array}{l}\text { Improved method of preventing } \\
\text { pests and diseases of maize }\end{array}$ & $59(56.2)$ & $26(24.8)$ & $20(19.0)$ & 248.85 & 2.37 & 0.788 & $11^{\text {th }}$ \\
\hline $\begin{array}{l}\text { Prevailing maize crop prices in } \\
\text { the market }\end{array}$ & $66(62.9)$ & $5(4.8)$ & $34(32.4)$ & 128.1 & 1.22 & 0.519 & $12^{\text {th }}$ \\
\hline Use of tractor for ridging & $47(44.8)$ & $25(23.8)$ & $33(31.4)$ & 224 & 2.13 & 0.867 & $13^{\text {th }}$ \\
\hline Use of tractor for harrowing & $47(44.8)$ & $25(23.8)$ & $33(31.4)$ & 224 & 2.13 & 0.867 & $14^{\text {th }}$ \\
\hline Soil management practices & $40(38.1)$ & $21(20.0)$ & $44(41.9)$ & 205.8 & 1.96 & 0.898 & $15^{\text {th }}$ \\
\hline $\begin{array}{l}\text { Mechanized method of shelling } \\
\text { maize grain }\end{array}$ & $34(32.4)$ & $9(8.6)$ & $62(59.0)$ & 181.65 & 1.73 & 0.923 & $16^{\text {th }}$ \\
\hline Loan acquisition/credit facilities & $31(29.5)$ & $3(2.9)$ & $71(67.6)$ & 170.1 & 1.62 & 0.913 & $17^{\text {th }}$ \\
\hline Soil fertility testing & $17(16.2)$ & $25(23.8)$ & $62(59.0)$ & 162.75 & 1.55 & 0.772 & $18^{\text {th }}$ \\
\hline $\begin{array}{l}\text { Environmental protection on } \\
\text { land }\end{array}$ & $11(10.5)$ & $36(34.3)$ & $58(55.3)$ & 161.07 & 1.54 & 0.694 & $19^{\text {th }}$ \\
\hline $\begin{array}{l}\text { Better record keeping on sales } \\
\text { produced }\end{array}$ & $12(11.4)$ & $28(26.7)$ & $65(62.0)$ & 156.45 & 1.49 & 0.709 & $20^{\text {th }}$ \\
\hline $\begin{array}{l}\text { Marketing of maize produced } \\
\text { through cooperatives }\end{array}$ & $4(3.8)$ & $16(15.2)$ & $84(80.0)$ & 128.1 & 1.22 & 0.519 & $21^{\text {st }}$ \\
\hline $\begin{array}{l}\text { Government policies on land } \\
\text { acquisition }\end{array}$ & $3(2.9)$ & $12(11.4)$ & $89(84.8)$ & 121.8 & 1.16 & 0.463 & $22^{\text {nd }}$ \\
\hline $\begin{array}{l}\text { Storage of maize in modern } \\
\text { cribs/silo }\end{array}$ & $6(5.7)$ & $1(1.0)$ & $98(93.3)$ & 115.5 & 1.10 & 0.479 & $23^{\text {rd }}$ \\
\hline $\begin{array}{l}\text { Payment of compensation for } \\
\text { crop }\end{array}$ & $5(4.8)$ & $1(1.0)$ & $99(94.3)$ & 114.45 & 1.09 & 0.441 & $24^{\text {th }}$ \\
\hline $\begin{array}{l}\text { Mechanized method of } \\
\text { harvesting maize }\end{array}$ & $4(3.8)$ & $\begin{array}{l}\text { 100(95. } \\
\text { 2) }\end{array}$ & $1(1.0)$ & 112.35 & 1.07 & 0.399 & $25^{\text {th }}$ \\
\hline
\end{tabular}

Source: Field Survey, 2015. 


\section{Sources of information used by the respondents}

Table 4 shows that (100\%) of the maize farmers in the area use radio as their main source of information medium. This may be due to the fact that radio is cheap, mobile and affordable to the farmers. This result supports the findings of Morgan (1993) in a study carried out in Kenya which showed that $80 \%$ of the populations were radio listeners. Moreover, Helen and Amin (2002) found that the radio remains the most important medium for communicating with the rural populations of developing countries. The percentage of respondents using television as source of information is high (68.6\%). This may be because television is an audio-visual device which is very effective in disseminating information and aids easy and fast understanding because of its two-way effect and this goes in line with Munyua (2000) who asserted that television, audiovisuals, print technology among others would be of great help to farmers in this information age. The result further shows that $28.6 \%$ use mobile phone as source of information. This implies that most of the farmers do not use mobile phone contact as a means of accessing information. This may be because of the cost of buying the phone or the airtime cost they are to use when they want to ask for any information that is high call rates. Also, the result shows that $54.3 \%$ of the farmers obtain information through the extension agent. This implies that great proportion of the respondents have contact with extension agent. This may give the farmers opportunity of face-to-face contact and probably participate and observe the Small Plot Adoption Technique (SPAT) demonstrations conducted by the extension agents. This agrees with Swanson (1997) that farmers do better in what they see and practice than what they hear only. Also, the findings show that $65.7 \%$ of the farmers use friends and neighbours as source of agricultural information. This implies that farmers communicate with one another because they live near each other and participate in almost the same cropping system.

Table 4: Distribution of respondents by sources of information used

\begin{tabular}{|c|c|c|}
\hline Sources of information & Yes & No \\
\hline Radio & $105(100)$ & $0(0)$ \\
\hline Television & $72(68.6)$ & $33(31.4)$ \\
\hline Mobile phone & $30(28.6)$ & $75(71.4)$ \\
\hline Extension Agent & $57(54.3)$ & $48(45.71)$ \\
\hline $\begin{array}{l}\text { Non-government } \\
\text { organization/Research } \\
\text { institute }\end{array}$ & $9(8.6)$ & $96(91.4)$ \\
\hline Newspaper & $5(4.8)$ & $100(95.2)$ \\
\hline Friends and Neighbours & $69(65.7)$ & $36(34.3)$ \\
\hline Agricultural pamphlets & $9(8.6)$ & $96(91.4)$ \\
\hline
\end{tabular}




\begin{tabular}{lll}
\hline Cooperative Society & $11(10.5)$ & $94(89.5)$ \\
Contact farmers & $49(46.7)$ & $56(53.3)$ \\
\hline
\end{tabular}

Source: Field Survey, $2015 . \quad$ Percentages are in parenthesis

\section{Test of hypothesis}

$\mathrm{HO}_{1}$ : There is no significant relationship between socio-economic characteristics of the maize farmers and their access to agricultural information.

Table 5: Result of correlation showing farmers' access to agricultural information

\begin{tabular}{|c|c|c|c|}
\hline Variables & Correlation & Access & Decision \\
\hline \multirow[t]{3}{*}{ Age } & Pearson correlation & $.230^{*}$ & \\
\hline & Sig.(2-tailed) & .018 & Significant \\
\hline & $\mathrm{N}$ & 105 & \\
\hline \multirow[t]{3}{*}{ Marital status } & Pearson correlation & $.369^{* *}$ & \\
\hline & Sig.(2-tailed) & .000 & Significant \\
\hline & $\mathrm{N}$ & 105 & \\
\hline \multirow[t]{3}{*}{ Education status } & Pearson correlation & $.552^{* *}$ & \\
\hline & Sig.(2-tailed) & .000 & Significant \\
\hline & $\mathrm{N}$ & 105 & \\
\hline \multirow[t]{3}{*}{ Farm size } & Pearson correlation & .163 & \\
\hline & Sig.(2-tailed) & .096 & Not significant \\
\hline & $\mathrm{N}$ & 105 & \\
\hline \multirow[t]{3}{*}{ Farm experience } & Pearson correlation & $.213^{*}$ & \\
\hline & Sig.(2-tailed) & .029 & Significant \\
\hline & $\mathrm{N}$ & 105 & \\
\hline \multirow[t]{3}{*}{ Household size } & Pearson correlation & $.232^{*}$ & \\
\hline & Sig.(2-tailed) & .017 & Significant \\
\hline & $\mathrm{N}$ & 105 & \\
\hline \multirow[t]{3}{*}{ Contact with E.A } & Pearson correlation & $.458^{* *}$ & \\
\hline & Sig.(2-tailed) & .000 & Significant \\
\hline & $\mathrm{N}$ & 105 & \\
\hline Organization & Pearson correlation & $.435^{* *}$ & \\
\hline \multirow[t]{2}{*}{ member } & Sig.(2-tailed) & .000 & Significant \\
\hline & $\mathrm{N}$ & 105 & \\
\hline Access & $\begin{array}{l}\text { Pearson correlation } \\
\text { Sig.(2-tailed) }\end{array}$ & 1 & \\
\hline
\end{tabular}


${ }^{*}$ Correlation is significant at the 0.01 level, ${ }^{* *}$ Correlation is significant at 0.5 level, ${ }^{* * *}$ Correlation is significant at 0.10 level ( 2 tailed) Source: Field Survey, 2015

Table 5 shows that age, marital status, educational status, farm experience, household size, contact with extension agent and organization membership are positive and significantly correlated with maize farmers access to agricultural information while farm size is statistically insignificant. This implies that the older the farmers' age the more their access to agricultural information, the higher their level of their education, the more access they have to information. In the same vein, how frequent they have contact with extension agent determine their level of access to agricultural information Similarly, the higher their level of participation in organizations like cooperative society the more their access to agricultural information. The result also shows that married farmers has more access to agricultural information than the single and divorced.

\section{Conclusion and recommendations}

The study revealed that maize farmers have limited access to agricultural information. This is because most of the information they have access to are majorly on technique of production, control of pest and diseases, market outlet and price. However, the farmers have limited information on record keeping, improved storage and preservation methods, control of erosion and flooding. The study, therefore, recommends that extension agency should provide farmers with up-to-date information and technology that can improve their skills in all these areas that they are deficient in relevant information.

\section{References}

Adebayo, S. A. and Adekunle, O. A. (2016). Socio-economic status of women in group membership in selected areas of Kwara State, Nigeria. Agrosearch 16(1): 57 - 64.

Adedoyin, I.S. (2006). Monetary Aggregate Targeting and Inflation in Nigeria. Agrosearch, 8(1): 8192.

Adesiji, G. B, Omotesho, K. F, Bolarin, O. and Aigbavboa, P. (2012). Assessment of Training Needs of Cashew Farmers in Owan East Local Government Area of Edo State, Nigeria. Agrosearch 12(2): $184-195$

Abdulrahaman, A.A. and Kolawole O.M (2008). Traditional Preparations and Uses of Maize in Nigeria. Traditional preparatoins and uses of maize in ngieria.htm

Aina, L O; Kaniki, A. M., \& Ojiambo, J. B. (1995). Preface. In Aina, L O.; Kaniki, A. M., \& Ojiambo, J.B. (Eds); Agricultural Information in Africa. Third World Information Services, Ibadan. 
Akande, S.O. (1999). A study of Agricultural Research system of Nigeria. NISER Monograph Series No. 6. Nigeria Institute of Social and Economic Research (NISER) Ibadan.

Balit, S., Calvelo Rios, M., \& Masias, L. (1996). Communication for development for Latin America: a regional experience. FAO, Rome Italy.

Coronado, G.D.; Thompson, B.; Strong, L.; Griffith, W.C.; Islas, I. (2004). Agricultural task and exposure to organophosphate pesticides among farm workers. Environ. Health18 Persp., 112., $142-147$.

FAO (1993). Agricultural Extension and Farm Women in the 1980s. Rome FAO Series 0125. pp. $1-6$

Fawole, O.P. (2008). Pineapple farmers' information sources and usage in Nigeria. Bulgarian Journal of Agricultural Sciences, 14(4): 381 - 389.

Helen H.O, Amin K. (2002). Listening to stakeholders. Agricultural Research and Rural Radio Linkages. International Service for National Agricultural Research (ISNAR). Briefing paper No. 48. April, 2002. The Hague, Netherlands.

International Institute of Tropical Agriculture (IITA) (2001). International Institute of Tropical Agriculture, Annual Report on Maize. IITA publication.

King, J.E. (1992). Labour Economics. London. Macmillan Publishers.

Khawar Jabran, Zahid Ata and Muhammad Farooq, (2007). Maize: Cereal with a Variety of Uses. DAWN- Business.http://wwwdawn.com/2007/03/12/ebr5.htm

Morgan, K.I. (1993). Research Findings on Rural Radio Listenership in Meru and Thuraka Nithi District Kenya. Nairobi: Agricultural Information Centre.

Moser C, Barrett C, Minten B (2005). Missed opportunities and missing markets: Spatialtemporal arbitrage of rice in Madagascar. Selected paper presented at the American Agricultural Economists Association Annual meeting, Providence, Rhode Island, July 24-27, 2005

Munyua, H. (2000). Apllication of information communication technologies in the National Agricultural Research Project (NARP). (1994). National Agricultural Research Strategy Plan for Nigeria (North-West Zone: Draft Report.

Ogunwale, A.B. (2005). Implementation of the training and visit system of extension service in Oyo State Agricultural Development Programme (ADP) in Nigeria. International Journal of Applied Agriculture and Apicultural Research, Faculty of Agricultural Sciences, Ladoke Akintola University of Technology, Ogbomoso, Nigeria.2(1): 147 - 155.

Opara, U. N. (2010). Personal and socio economic determinants of agricultural Origin, History and Uses of Corn. lowa State University, Department of Agronomy. February 11, 2014.

Konradsen, F.; Van der Hoek, W.; Cole, D.C.; Hutchinson, G.; 1 Daisley, H.; Singh, S., Eddleston, M. (2003). Reducing acute poisoniang in developing countries-options for restricting the availability of pesticides. Toxicology, 192: 249-261 
Swanson, B. E, (1997). The Changing Role of Extension in Technology Transfer. J. International Agric. And Extension Education 4(2). 87 - 94pp.

Uchezuba I.D, Moshabele E, and Digopo D, (2009). Logistical estimation of the probability of mainstream market participation among small-scale livestock farmers: a case study of the Northern Cape Province. Agreko, 48(2): 171 - 1

Xaba B.G, and Masuku M.B, (2012). Factors Affecting the Choice of Marketing Channel by Vegetable Farmers in Swaziland. Internet file retrieved on 5th May 2013 from: http://dx.doi.org/10.5539/sar.v2nlp112

Zijp W. (1994) Improving the transfer and use of agricultural information- A guide to information technology. Washington DC World bank. zones of Imo state, Nigeria. Library Philosophy and Practice. 